\title{
UPAYA PERAWAT DALAM MEMBERIKAN PROMOSI DAN EVALUASI PENERAPAN BUDAYA KESELAMATAN PASIEN
}

\author{
Nuraini Sihite \\ Email: nurainisihite4@gmail.com
}

\section{Latar belakang}

Pelaksanaan promosi kesehatan rumah sakit (PKRS) sangat bermanfaat untuk menambah wawasan untuk pasien dan keluarganya, serta pengunjung di rumah sakit tentang beragam jenis penyakit serta langkah apa saja yang diperlukan untuk pencegahannya, selain itu promosi kesehatan di rumah sakit merupakan upaya rumah sakit untuk meningkatkan kemampuan pasien, keluarga dan pengunjung rumah sakit agar dapat berperan secara positif dalam usuha penyembuhan dan pencegahan terhadap penyakit sehingga dapat mempercepat proses penyembuhan serta rehabilitasi, meningkatkan kesehatan, mencegah terjadinya penyakit, serta mengembangkan berbagai upaya untuk meningkatkan kesehatan masyarakat melalui pembelajaran sesuai dengan sosial dan budaya masing masing secara mandiri.

Tujuan dari promosi kesehatan rumah sakit adalah agar terciptanya masyarakat rumah sakit yang mampu menerapkan perilaku hidup bersih dan sehat (PHBS) melalui perubahan pengetahuan, sikap, dan perilaku pasien rumah sakit serta pemeliharaan lingkungan rumah sakit dan dapat memanfaatkan semua pelayanan yang disediakan oleh rumah sakit dengan baik.

Membangun budaya keselamatan pasien merupakan langkah awal dalam pengembangan keselamatan pasien. Budaya keselamatan merupakan nilai, persepsi dan perilaku yang dianut oleh setiap individu di organisasi. Setiap individu dan bertanggung jawab terhadap keselamatan berperilaku menjaga meningkatkan dan mengkomunikasikan tentang keselamatan, berusaha untuk belajar aktif dan setiap kesalahan yang terjadi.

Budaya keselamatan pasien merupakan nilai kepercayaan yang dianut bersama dan berkaitan dengan struktur organisasi dan sistem pengawasan dan 
pengendalian untuk menghasilkan norma norma perilaku titik budaya keselamatan di pelayanan kesehatan diartikan sebagai keyakinan, nilai perilaku yang dikaitkan dengan keselamatan pasien yang secara tidak sadar diangkat bersama oleh anggota organisasi.

Budaya keselamatan pasien merupakan hal yang penting dalam keselamatan pasien. Membangun budaya keselamatan pasien merupakan suatu cara untuk mewujudkan keselamatan pasien secara keseluruhan. Fokus pada budaya keselamatan pasien akan lebih berhasil apabila dibandingkan hanya fokus pada program keselamatan saja budaya keselamatan pasien merupakan langkah awal dalam mewujudkan keselamatan pasien

\section{Metode}

Metode yang digunakan pada kajian ini adalah metode kualitatif yang memberikan penjelasan dengan menggunakan analisis pada referensi yang digunakan. Untuk mengumpulkan data-data dari beberapa jurnal dan e-book dari situs internet yang berhubungan dengan topik pembahasan yaitu upaya perawat dalam memberikan promosi dan evalusi penerapan budaya keselamatan pasien. Karena keterbatasan waktu, cakupan luas dari topik, dan untuk lebih spesifik, maka dilakukan batasan waktu pada tahun publikasinya dengan waktu minimalnya delapan tahun terakhir yaitu dari tahun 2012 dengan mengambil referensi yang terkait dengan topik yang digunakan.

\section{Hasil}

Keefektifan suatu pengobatan dan pengaruh pola pelayanan, seperti sikap dan keterampilan tim promosi kesehatan rumah sakit (PKRS) merupakan bagian penting dari promosi kesehatan di rumah sakit, lingkungan, sikap, pola hidup pasien dan keluarga pasien juga mempengaruhi keefektifan dari pengobatan yang diberikan oleh rumah sakit. Apabila seorang pasien dan keluarga pasien telah menguasai pengetahuan tentang berbagai macam penyakit beserta metode penyembuhan dan pencegahan penyakit tersebut, maka hal ini akan membantu proses penyembuhan penyakit pasien tersebut. 
Pelaksanan keselamatan dan kesehatan kerja Rumah Sakit merupakan kewajiban Rumah Sakit dalam memenuhi tuntutan pemerintah untuk mengadakan akreditasi dan keselamatan dan kesehatan kerja merupakan salah satu aspek penilaian dalam akreditasi tersebut.

K3RS diharapkan mampu menunjang pelayanan kesehatanRumah Sakit menjadi lebih baik. Selain itu, K3RS dapat dijadikan media preventif dan proteksi diri dari penyakit penyakit akibat kerja dan kejadian kejadian yang tidak di inginkan di Rumah Sakit.

Menciptakan budaya keselamatan pasien merupakan hal yang sangat penting. Hal tersebut dikarenakan budaya mengandung 2 komponen yaitu nilai dan keyakinan di mana nilai mengacu pada suatu yang diyakini oleh anggota organisasi untuk mengetahui apa yang benar dan apa yang salah sedangkan keyakinan mengacu pada sikap tentang cara bagaimana seharusnya bekerja dalam organisasi.

Hasil penelitian menunjukkan bahwa indikator budaya keselamatan pasien untuk kerjasama dan komunikasi dalam kategori baik. Sedangkan untuk kategori kepemimpinan, pelaporan dan respon tidak tidak menghukum di kategori cukup.

Untuk meningkatkan budaya keselamatan pasien, kesadaran perawat tentang pentingnya keselamatan pasien juga perlu ditingkatkan. Budaya keselamatan pasien merupakan faktor penting dalam upaya untuk mengurangi resiko yang merugikan di rumah sakit dan meningkatkan keselamatan pasien.

Dengan budaya keselamatan pasien terdapat budaya untuk melaporkan kesalahan ataupun kejadian nyaris cedera,laporan tersebut digunakan sebagai pembelajaran bagi organisasi dalam memperbaiki sistem pelayanan, budaya tersebut hanya dapat berkembang dalam suasana yang tidak memojokkan atau mempersalahkan individu sehingga tercipta keterbukaan dan sikap jujur. 


\section{Pembahasan}

Menurut keputusan Menteri Kesehatan Republik Indonesia No.432/MENKES/SK/IV/2007 Tentang Pedoman Kesehatan dan Keselamatan Kerja di Rumah Sakit, komitmen diwujudkan dalam bentuk kebijakan (policy) tertulis, jelas dan mudah dimengerti serta diketahui oleh seluruh karyawan Rumah Sakit. Ibrahim (2017)

Setiap Rumah Sakit wajib melaksanakan pelayanan kesehatan dan keselamatan kerja sesuai yang tercantum pada pasal 23 dalam Undang-Undang No. 36 tahun tahun 2009 tentang kesehatan dan Peraturan Menteri Tenaga Kerja dan Transmigrasi RI No.03/MEN/1982 tentang pelayanan kesehatan kerja.

Berdasarkan Undang-undang No. 44 Tahun 2009 tentang Rumah Sakit, disebutkan bahwa rumah sakit merupakan sebuah insititusi pelayanan kesehatan yang menyediakan segala jenis pelayanan kesehatan paripurna, berarti pelayanan yang diberikan termasuk pelayanan preventif, promotif, rehabilitatif dan kuratif.

Berdasarkan peraturan dari perundang-undangan tentang rumah sakit yaitu Permenkes No. 4 Tahun 2012 mengenai petunjuk teknis PKRS, menyatakan bahwa setiap rumah sakit harus melaksanakan usaha dalam meningkatkan kesehatan melalui berbagai macam kegiatan Promosi Kesehatan Rumah Sakit.

Terdapat 3 tahap untuk perencanaan terhadap pengembangan Promosi Kesehatan Rumah Sakit (PKRS) dalam Permenkes No. 4 Tahun 2012,yaitu:

1. Menyatukan segala pemahaman dan sikap terhadap mental yang positif dari para direksi, pemilik rumah sakit, dan petugas rumah sakit.

2. Mempersiapkan segala bentuk dan tugas kelembagaan PKRS

3. Mempersiapkan seluruh petugas yang telah memahami semua filosofi, prinsip-prinsip, tujuan dan sarana aksidari Promosi Kesehatan Rumah Sakit. Nurdianna (2017)

Menurut The Health Foudation, 2011, budaya keselamatan berkaitan dengan sejauh mana organisasi memprioritaskan dan mendukung peningkatan keselamatan dengan aman. Organisasi dengan budaya keselamatan positif 
memiliki komunikasi atas dasar saling percaya, persepsi bersama tentang pentingnya keselamatan, keyakinan pada efektivitas langkah-langkah pencegahan, dan dukungan bagi tenaga kerja. Iriviranty (2015)

Budaya keselamatan merupakan faktor penting untuk memahami upaya untuk memajukan perawatan pasien yang aman. Hasil ini memberikan implikasi kualitas pelayanan untuk kepemimpinan rumah sakit. Ketika para pemimpin memprioritaskan budaya keselamatan, resiko terhadap pasien mungkin telah diperbaiki dengan pergantian staf dan peningkatan produktivitas. Hal ini dapat dijadikan investasi dalam sistem keselamatan pasien untuk memberikan perawatan andal dan aman.

Untuk meningkatkan budaya keselamatan pasien, kesadaran perawat tentang pentingnya keselamatan pasien juga perlu ditingkatkan. Budaya keselamatan pasien merupakan faktor penting dalam upaya untuk mengurangi resiko yang merugikan di rumah sakit dan meningkatkan keselamatan pasien. Najihah (2018)

Budaya keselamatan pasien merupakan indikator kualitas penting dalam pelayanan kesehatan dan telah dikaitkan dengan hasil pasien yang diperoleh pasien di rumah sakit. Tingkat budaya keselamatan pasien adalah positif dan signifikan berkorelasi dengan tingkat pelaporan kesalahan. Budaya keselamatan Pasien, tempat lahir, kejadian error, dan tidak memiliki gelar keperawatan akademis merupakan prediktor signifikan dari pelaporan kesalahan. Penelitian ini menegaskan pengaruh iklim keselamatan untuk kesiapan melaporkan kesalahan. Eksekutif kesehatan dan manajer dapat membuat dampak besar pada pengembangan budaya keselamatan dengan menciptakan dan mempromosikan visi dan strategi untuk kualitas dan keselamatan dengan membina motivasi karyawan mereka untuk melaksanakan program peningkatan di tingkat departemen dan individu. Budaya keselamatan dapat mendorong pelaporan kesalahan oleh staf untuk meningkatkan keselamatan pasien.(Kagan \& Barnoy, 2013)

Budaya keselamatan pasien merupakan hal yang penting dalam keselamatan pasien titik membangun budaya keselamatan pasien merupakan suatu cara untuk 
mewujudkan keselamatan pasien secara keseluruhan. Fokus pada budaya keselamatan pasien akan lebih berhasil apabila dibandingkan hanya fokus pada program keselamatan saja. budaya keselamatan pasien secara garis besar dipengaruhi oleh empat dimensi yaitu terbuka (open), adil (just), dan informatif dalam melaporkan kejadian yang terjadi (reporting) dan belajar dari kesalahan yang ada (learning).kalau bersifat terbuka dan adil berarti berbagi informasi secara terbuka dan bebas, dan perlakuan adil bagi perawat ketika sebuah kejadian terjadi.

Dengan budaya keselamatan pasien terdapat budaya untuk melaporkan kesalahan ataupun kejadian nyaris cedera,laporan tersebut digunakan sebagai pembelajaran bagi organisasi dalam memperbaiki sistem pelayanan, budaya tersebut hanya dapat berkembang dalam suasana yang tidak memojokkan atau mempersalahkan individu sehingga tercipta keterbukaan dan sikap jujur.

Menciptakan budaya keselamatan pasien merupakan hal yang sangat penting. Hal tersebut dikarenakan budaya mengandung 2 komponen yaitu nilai dan keyakinan di mana nilai mengacu pada suatu yang diyakini oleh anggota organisasi untuk mengetahui apa yang benar dan apa yang salah sedangkan keyakinan mengacu pada sikap tentang cara bagaimana seharusnya bekerja dalam organisasi. Dengan adanya nilai dan keyakinan yang berkaitan dengan keselamatan pasien yang ditanamkan pada setiap anggota organisasi maka setiap anggota akan mengetahui apa yang seharusnya dilakukan dalam penerapan keselamatan pasien dengan demikian perilaku aku tersebut dapat akhirnya menjadi suatu budaya yang tertanam dalam setiap anggota organisasi berupa perilaku budaya keselamatan pasien.

manfaat utama dalam budaya keselamatan pasien adalah organisasi menyadari apa yang salah dan pembelajaran terhadap kesalahan tersebut. Manfaat lain dalam budaya keselamatan pasien antara lain:

1. Organisasi kesehatan lebih tahu jika ada kesalahan yang akan terjadi atau jika kesalahan telah terjadi 
2. meningkatkan laporan kejadian yang dibuat dan belajar dari kesalahan yang terjadi akan berpotensi menurunnya kejadian yang sama berulang kali dan keparahan dari keselamatan pasien

3. kesadaran akan keselamatan pasien, yaitu bekerja untuk mencegah error dan melepaskan jika ada kesalahan

4. Berkurangnya perawat yang merasa tertekan, bersalah, malu karena kesalahan yang telah diperbuat.

5. Berkurangnya turn over pasien, karena pasien yang pernah mengalami insiden, pada umumnya akan mengalami perpanjangan hari perawatan dan pengobatan yang diberikan lebih dari pengobatan yang seharusnya diterima pasien.

6. Mengurangi biaya yang diakibatkan oleh kesalahan dan penambahan terapi.

7. Mengurangi sumber daya yang dibutuhkan untuk mengatasi keluhan pasien.

\section{Penutup}

Budaya keselamatan pasien merupakan nilai, kepercayaan komanya Diana bersama dan berkaitan dengan struktur organisasi, dan sistem pengawasan dan pengendalian untuk menghasilkan norma norma perilaku. budaya keselamatan di pelayanan kesehatan diartikan sebagai keyakinan, nilai perilaku yang dikaitkan dengan keselamatan pasien yang secara tidak sadar dianut bersama oleh pasien. Untuk mewujudkan kesehatan masyarakat secara keseluruhan, keterampilan tenaga kerja rumah sakit maupun masyarakat baik pasien, keluarga pasien maupun pengunjung perlu untuk ditingkatkan dalam hal memelihara dan meningkatkan kesehatan.

\section{Daftar pustaka}

1. Hadi Irwan. 2017. Manajemen keselamatan pasien. Deepublish: Yogyakarta.

2. Simamora, R. H., \&Fathi, A. (2019). The Influence Of Training Handover Based SBAR Communication For Improving Patients Safety. Indian journal of public health research \& development, 10(9), 1280-1285. 
3. Najihah. 2018. Budaya keselamatan pasien dan insiden keselamatan pasien di rumah sakit: literature review. Volume 3 Nomor 1.

4. Ibrahim Hasbi, dkk. 2017. Gambaran penerapan standar manajemen keselamatan dan kesehatan kerja rumah sakit di rumah sakit umum daerah Haji Makassar. Volume 9, Nomor 2.

5. Nurdianna Fitri. 2017. Pelaksanaan promosi kesehatan di rumah sakit universitas Airlangga Surabaya. Jurnal Promkes Vol. 5 No. 2.

6. Iriviranty Afrisya. 2015. Analisis Budaya Organisasi dan Budaya Keselamatan Pasien Sebagai Langkah Pengembangan Keselamatan Pasien di RSIA Budi Kemuliaan Tahun 2014. Jurnal Administrasi Rumah Sakit Volume 1 Nomor 3.

7. Brito G T. 2015. Analisis aspek pembentukan budaya K3 dengan kepatuhan penggunaan APD pada pekerja produksi resin di Sidoarjo. The Indonesian Journal of Occupational Safety and Health, Vol. 4, No. 2.

8. Herawati Y T. 2015. Budaya keselamatan pasien di ruang rawat inap Rumah Sakit X kabupaten Jember. Jurnal IKESMA Volume 11 Nomor 1.

9. Ismainar Hetty. 2019. Keselamatan pasien di rumah sakit. Yogyakarta: Deepublish Publisher.

10. Rangkuti D.S.R, dkk. 2018. Analisis penyebab ketidaktepatan waktu pelaporan insiden keselamatan pasien di RSU BUNDA THAMRIN. Vol 1 No2.

11. Yasmi Yulia, Hasbullah Thabrany. 2018. Faktor-Faktor yang Berhubungan dengan Budaya Keselamatan Pasien di Rumah Sakit Karya Bhakti Pratiwi Bogor Tahun 2015. Jurnal Administrasi Rumah Sakit Volume 4 Nomor 2 